\section{More than Just} Making

\section{The Ezra Jack Keats Bookmaking Competition}

\author{
DEBORAH POPE, MELISSA JACOBS, AND KAREN ROSNER
}

$\mathrm{M}$

aking students happy while they learn is a core mandate of the Ezra Jack Keats Foundation (EJK), as is the support and enrichment of public schools, libraries, and the educators within. For more than thirty years, the Ezra Jack Keats Bookmaking Competition has realized our mandate by providing librarians and teachers with an inclusive activity that students on every level of proficiency enjoy even as they improve all of their literacy skills.

Such a program is only possible through collaboration and the extended efforts of administrators and educators. For many years, we at EJK have worked with the New York City Department of Education (DOE) employees Karen Rosner, director of visual arts (from the Office of Arts and Special Projects) and Melissa Jacobs, director of library services. The third institution instrumental in realizing the program is Brooklyn Public Library (BPL), which, under the leadership of President and CEO Linda E. Johnson, provides a home for the jury deliberations, the exhibition of winning and honorable mention books, and the award ceremony. Kimberly Grad, the BPL Bookmaking coordinator, is a critical member of the team.

The EJK Bookmaking Competition includes students divided into three groups-elementary (grades 3-5), middle school (grades 6-8), and high school (grades 9-12). Within these

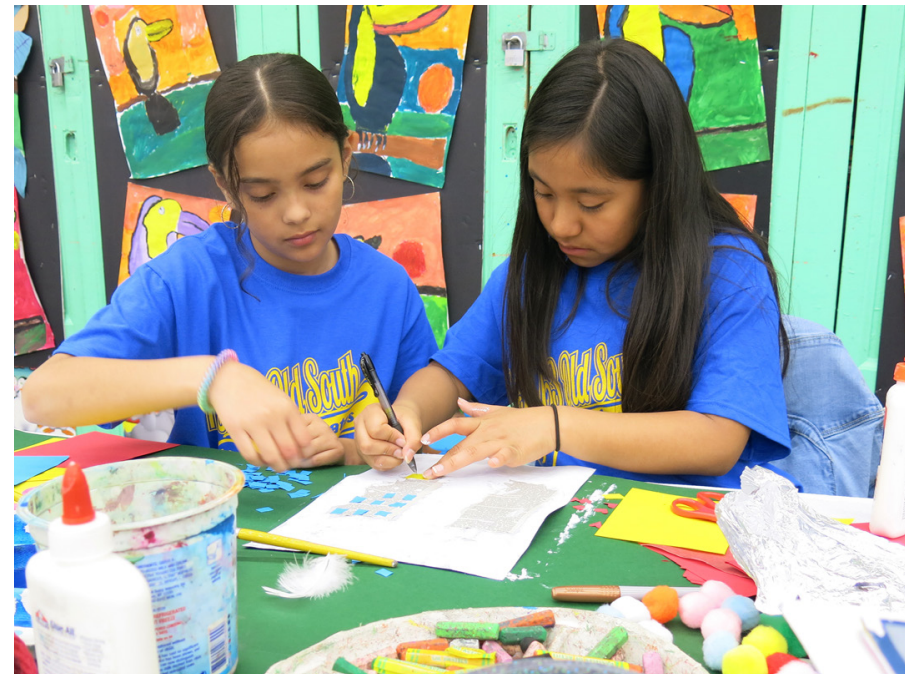

Grades 3-5: Dasha and Mariana work on bookmaking (all photos by Diane Vozza).

groups, the activity engages students, from reluctant to motivated, allowing each child to excel at their own pace and level.

Any number of students or classes in one school can participate; one book is chosen to be the school winner and submitted to the DOE for consideration as a borough or city winner. This gives every school an equal chance at having a winning entry. City-wide winners receive a medal and $\$ 500$; borough winners get a medal and $\$ 100$; and the teachers or librarians who advised them receive a gift certificate for new books. Each school is encouraged to have a celebration of all the books made, and every student who completes a book receives a certificate of commendation. The school winner's books all receive medals, as well as certificates.

Once submitted, the school winners are judged by a panel assembled by Kim Grad at BPL. The panel includes librarians, children's book authors and illustrators, and experts from schools of education and trade periodicals. The winners receive a check, as well as a medal at an award ceremony at the end of the school year during which honorable mention books are also celebrated. Along with the creation of a stunning catalog, there is a three-week exhibition featuring the winning and honorable mention books at the Central Branch of BPL.

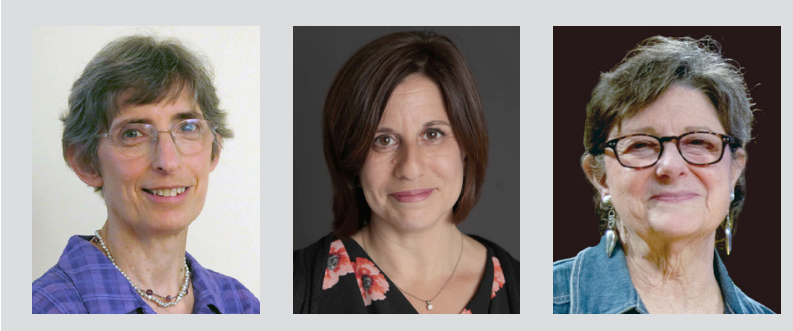

Deborah Pope, Executive Director of the Ezra Jack Keats Foundation, focuses on increasing diversity in children's literature, enriching public education, and making reading and learning fun for kids. Melissa Jacobs is the Director of Library Services for the New York City Department of Education. Karen Rosner is the Director of Visual Arts for the New York City Department of Education, supervising initiatives that support visual arts educators and professional development for K-12 art teachers citywide. 
Bookmaking engages students by giving them control over their learning experience. The subjects tackled by the students range from the loss of a parent to how to tie your shoelaces, from a voyage through a mythical kingdom to the number zero's journey to a sense of self-worth, from the joy of playing the violin to dealing with bullies.

Each child creates their book for a different reason. For some it is a way of working out an emotional issue, such as what fourth grader London Sims says: "This book is very dear to my heart. Every part of making this book reminds me of my dad."

For others the activity is the beginning of realizing a life goal, such as for twelfth grader Alex Trinidad: "One day I would like to be a city planner, and as I worked I imagined what it would be like to visit these buildings and landmarks."

Then there are the students who want to create a book that will send a message they would have liked to receive. Alicia Lee, an eighth grader, said, "The idea of writing something I would've wanted to read as a child made me grow more attached to [my book] and to its main character.... It's important for me to teach young readers to value and be proud of themselves."

Bookmaking motivates students to rewrite and revise, to improve their grammar, spelling and syntax, because they want to tell their story clearly and effectively. Then, having written or illustrated their own book, the student's perspective changes. Their experience makes them more analytical and thoughtful readers.

Sabrina Aquilone, grade 8, said, "Bookmaking was a long process that I enjoyed. It was an experience that made me realize that the plotline and illustrations must follow from the beginning to the end."

In addition to building self-esteem and confidence through achieving a difficult goal and having their work appreciated by others, the program strengthens a sense of community within the classroom. Undervalued students become successful participants in a class project and have their talents recognized by the group, perhaps for the first time.

Librarian Kathleen Fleischmann and teacher Maria Panatopoulou, who have collaborated on EJK Bookmaking for four years at PS 63Q in Queens, New York, offered a wonderful description of how students benefit from the work:

As part of the process, they learn to be disciplined and responsible for their creative process. They also learn time management. These are wonderful skills that they take into adulthood. Additionally,

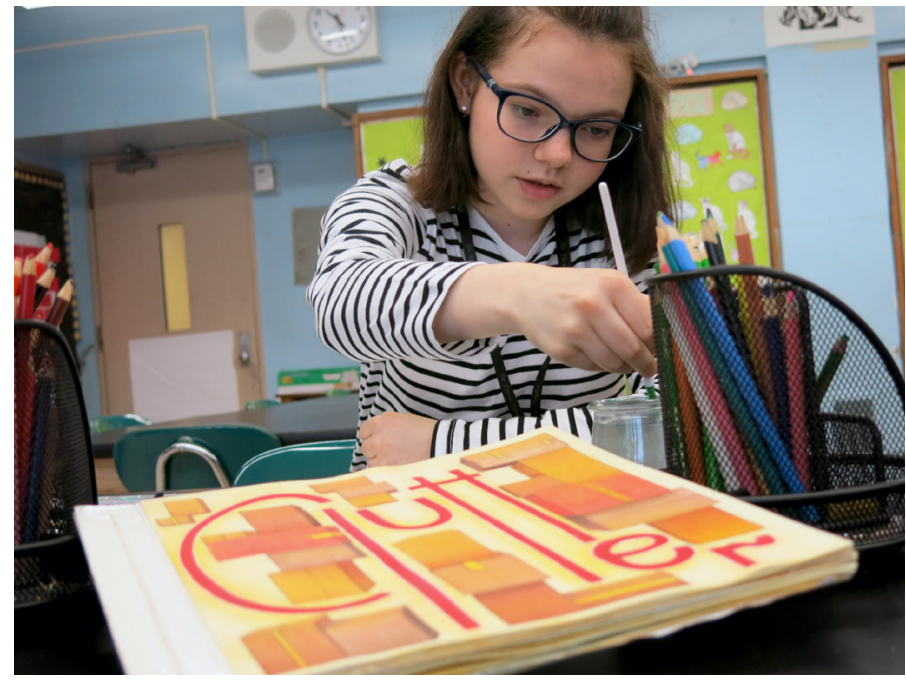

Grades 6-8: Sofia works to get it just right.

those working on nonfiction books hone their research skills. Whether working collaboratively or not, they form bonds with and support each other, share ideas, and give feedback. By going through this process, whether they win or not, there is a huge benefit and potential impact on their future.

Fleischmann and Panatopoulou agree that their collaboration has made a huge difference. This dedicated team also makes it very clear they wouldn't be able to succeed without the buy-in and support of their principal, Diane Marina.

This school-wide collaboration reflects the team effort this program inspires, from the top down. Jacobs and Rosner clearly share this inspiration, as demonstrated by their description of their experience of the program. Jacobs said,

As a school librarian, there are always those exhilarating projects you wait all year to lead with your students. For me, that project was bookmaking. I fell in love with the writing, creativity, and innovation that bookmaking had to offer. In my first year as an elementary school librarian in a NYC public school, I was delighted to learn about the citywide competition offered by the EJK Foundation and pleased the Foundation offered a monetary incentive to winners.

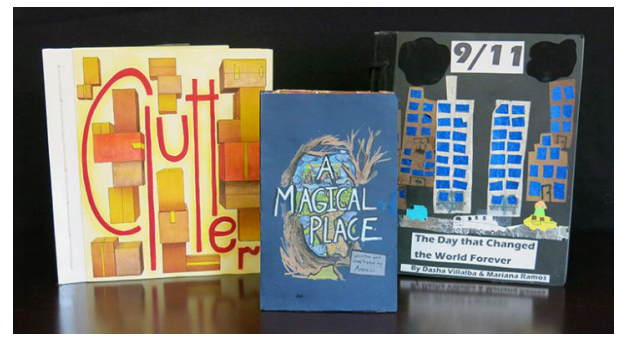

I kicked off my initial program by collaborating with the art teacher and developing an after-school Bookmaking Enrichment Club. I promoted bookmaking as a part of the classroom curriculum, tied it to the library curriculum, and organized a school-wide event to 
select the winner that would go on to the city-wide competition. The EJK Bookmaking Competition helped me create a culture of writers and artists in the school while enriching the school's literacy-focused environment.

Two decades later... I have developed a new program to help sustain the competition for future generations and connect bookmaking to the makerspace initiative in school libraries. A makerspace is a type of learning lab where students gather to create, innovate, do-it-yourself, invent, learn, design, explore, and discover. Makerspaces can be low-tech or high-tech, are limited only by one's imagination, and tie-in perfectly to the arts and bookmaking.

The EJK Bookmaking Makerspace Grant is a part of the NYC School Library System's INNOVATION! Makerspace Program. The objective is to provide instruction, supplies, and create a sustainable program in the school library that encourages bookmaking, writing, and the arts throughout the school year. The grant provides makerspace materials and professional development to school librarians serving grades 3-12.

Each grant winner receives a customized assortment of art supplies, a professionally curated collection of books that included art-centric and diverse picturebooks, as well as interactive pop-up books, and an art cart to organize the makerspace. The full-day, hands-on, professional-development workshop was facilitated by Dr. Zetta Elliott and artist and art consultant Jo Beth Ravitz. Participants learned how to engage and empower students through creative writing, how to encourage students to write a story, and how to turn their stories into an illustrated picturebook.

Each participating school librarian submitted one studentcreated picture book to the

"At first I thought it would be easy to create a book, but it turned out to be much more difficult. . . . I worked in class and on the weekends at home. The book took me about a month to complete. ... I want to thank all my teachers and especially my art teacher, Ms. Skopp, for all the inspiration and help."

Solomon Birmakher, grade 4 sense of satisfaction students derive when they recognize how they persisted and achieved their goals. In addition, recognizing how collegiality is so important to a school's environment, I am dedicated to a program that promotes true collaboration.

The Office of Arts and Special Projects has facilitated many aspects of the Bookmaking Competition for over three decades, including professional learning experiences for art teachers, classroom teachers, and librarians, outreach to schools, the gathering and return of all submissions, the editing of student entries for the catalog, and involvement in the year-end celebration. competition. As a result, the number of entries increased this past year with an additional thirty submissions. Next year, we hope to have sixty additional submissions and are scheduled to offer another grant with an added bonus for the librarians who've already participated. These experienced librarians will attend the professional development session in the afternoon, share their expertise and "shop" for additional art supplies ordered by the NYC School Library System. Rosner added,

I am dedicated to this program for many reasons. It emphasizes the important role of picturebooks in a child's education, the deep learning students experience as they engage in the creative process of making their own books, and the
Beyond the creation of a final entry, the one book chosen by the school to be entered into the competition is a dynamic engine at work that involves so many individuals. Participating schools often have an entire class, and sometimes more than one class, involved in the writing and illustrating of picturebooks. This often translates into thirty to fifty students per school immersed in analyzing picturebooks, engaged in author studies, and sharing work with peers. Frequently, a celebration of student presentations is the culmination of the bookmaking program at the school level.

The school level team may include partnerships among the art teacher, classroom teacher, and the school librarian, along 
with the support of school administrators, making the Ezra Jack Keats Bookmaking Competition a true collaborative effort.

Bookmaking makes that excellence something you can hold in your hand and show to others to prove you've done your work well. We look forward to more and more educators bringing this program into their classrooms. \&

For more information about the EJK Bookmaking Competition, including a video about the process, visit www.ezra-jack-keats .org/section/ezra-jack-keats-bookmaking-competition/.

\section{Taking Great Photos. . . And Getting Them in Print}

Everyone can benefit from free publicity, right? And Children and Libraries (CAL) is pleased to serve as a venue to promote your libraries' programs and practices. In fact, we'd like to run more photos of library events in CAL, but we need the help of our readers to provide us with good, usable photos.

To that end, we've prepared this guide for taking photos at your library-photos that will not only serve your library and local media but can readily be used in CAL as well.

1. The Camera Counts. Almost everyone now uses a digital camera or has access to one. But all digital cameras (and smartphones) are not created equal. Generally, those with a higher megapixel count will provide the clearest images with best resolution. A digital camera of 7 megapixels or more should be able to take a photo with high enough resolution for print reproduction.

2. What's DPI? For photos to be reproduced in magazines such as CAL, we require digital images of 300 DPI (dots per inch) or higher. It may be hard to tell on your camera what the end resolution will be, but here's a handy rule of thumb. Just set your camera to take photos on its highest resolution setting. That's usually the setting that will take the FEWEST photos. That's one common mistake most libraries make; they set the camera to take the MOST photos, but those are generally too small to use in print.

3. Print vs. Internet. There are different requirements for photos used in print publications and on the web. We cannot download photos from a library website unless they are already high enough resolution.

4. Composition Matters. When you're taking pictures at an event (such as storytime, book signings, etc.), keep an eye out for what would make a nice photo. Don't just snap away. Consider that a photo with two or three smiling children will make a much better photo than a group of forty kids. While it's important to take photos of the entire group to document the success of the program, snap a few closeups of kids' faces; these will often make the biggest impact, especially in a magazine spread. Candid shots are especially good, too, such as catching the little child paging through a board book or building a block house.

5. Seek out Photographers. If you're too busy the day of a library event to act as photographer, seek out someone who can and will document the event. This might be a willing parent, a library volunteer, or even a local high school or college student looking to get some photography clips for their portfolio. They will likely capture things you might miss or overlook during the event.

6. Get Permissions. In this day and age, getting permissions to take and use photographs of children is essential -both for libraries and for publications. CAL cannot run any photos of children without having a signed permission/release form from the child's parent or guardian. Most libraries now regularly have such release forms available during their events; if your library doesn't, you may want to consider this. It's easier to get the permissions during the event than tracking the parents down later. The release forms don't need to be full of legalese, just short forms noting that the parent/guardian gives permission for the child's photo to be used in any publication/publicity connected to the library and its programs.

Document those special moments at your library, and send them to us; we'd love to use them in an upcoming issue of CAL! \& 